\title{
Organizational Culture Artifacts and Compassionate Human Resources Practices in a Healthcare Organization
}

\author{
Merlin Patricia Grueso-Hinestroza ${ }^{1}$, Mónica López-Santamaría $^{1}$, Javier L González $^{1}$, Wilmer Salcedo ${ }^{2}$ \& \\ Marysella Amaya ${ }^{3}$ \\ ${ }^{1}$ School of Management and Business, Universidad del Rosario, Bogotá, Colombia \\ ${ }^{2}$ Master in Health Management, Kaika S.A.S, Bogotá, Colombia \\ ${ }^{3}$ Master in Health Management, Fundación Prosperar, Mosquera, Cundinamarca \\ Correspondence: Merlin P Grueso, Calle 12C \# 6-25, Universidad del Rosario, Bogotá-Colombia. Tel: \\ 57-297-0200 Ext: 3941. E-mail: merlin.grueso@urosario.edu.co
}

\author{
Received: February 1, 2018 \\ Accepted: February 20, 2018 \\ Online Published: March 20, 2018 \\ doi:10.5539/ass.v14n4p90 \\ URL: https://doi.org/10.5539/ass.v14n4p90
}

\begin{abstract}
Compassion in organizations and their determinants is a research topic that is still underdeveloped, in consequence, a study was carried out with a sample of 112 employees in a health services organization in Bogotá (Colombia). To achieve this goal, the Organizational Culture Artifact Questionnaire -OCSA- and the Compassion Organizational Practices Questionnaire were administered. The results show that the organizational culture through its artifacts predicts in a significant way the adoption of compassion organizational practices. In analyzing the type of culture that has the greatest predictive power over compassionate organizational practices, it has been found that progressive culture has the greatest effect, in contrast to traditional culture. The conclusions discuss the practical implications of the study and its limitations.
\end{abstract}

Keywords: Compassionate organizational practices, culture artifacts, healthcare, humanization, service

\section{Introduction}

When talking about humanization in health care, it is necessary to consider a set of values that require training professionals in this area to achieve the proficiency that will guarantee quality care (Correa, 2016). A work culture that emphasizes the promotion of a shared vision of the interests of these professionals contributes to the configuration of a work community (O'brien, 2006), and in this process of community formation, compassion helps in bolstering links between people (Kanov et al., 2004).

Given that during the last thirty-five years the social sciences in Latin America have transformed their research agendas (Enríquez, 2015), it is found that some researchers and professionals have recently begun to pay more attention to compassion at work, after realizing that employees' suffering within an organization entails an inordinate cost in financial, psychological and social terms (Moon, Hur, Ko, Kim \& Yoon, 2016). On the latter, Dutton, Workman \& Hardin (2014, p. 280) indicate that "suffering is a general phenomenon in the workplace. Statistics on pain, stress and exhaustion reveal that suffering is costly".

In contrast with the aforesaid, Lilius, Kanov, Dutton, Worline and Maitlis (2011) point out that the practice of compassion generates positive results. These authors, furthermore, examine how compassion could manage to have a beneficial effect on organizations, employees and clients. According to Friedman and Gerstein (2017), compassion can be a powerful ingredient that makes an organization thrive.

There is evidence of the importance of recognizing and rewarding compassionate practices in healthcare organizations. McClelland and Vogus (2014) point out that when there are compassionate practices in an organization, the traumas experienced in the daily work are faced with greater capacity and a context is created in which it is easier to discover, feel and respond to suffering. Chu (2016), for his part stresses that in organizations which promote deeds that increase the positive side of helping the other and the reward for them, the number of benevolent actions increase.

Despite the relevance of the issue in the organizations, research on compassion remains limited (Chu, 2016; McClelland, Gabriel, \& DePuccio, 2018). Dutton et al. (2014) agree with this assessment and they highlight the 
need for studies in this area to continuously deepen. According to Tierney (2018), in health services research, compassion have been little discussed.

One of the main gaps in compassion research within organizations is that of its relationship with culture (Lilius et al., 2008). Saunders (2015) points out the importance of moving forward in the understanding of the organizational culture as a fundamental element to reach an effective compassion. According to Beardsmore and McSherry (2017), compassion can be directly influenced by culture. Dutton et al. (2014), in their theoretical model argue that the organizational culture, as a set of shared norms and values, determines the expression of compassion within organizations; however, they recognize the need to do more research aimed at aiding the comprehension of mechanisms of compassion institutionalization in work contexts.

Based on the above, the aim of this paper is to analyze the relationship between the organizational culture (understood through its artifacts) and compassion practices. A sample of employees from a healthcare organization was used. With this aim, the paper is structured in a manner described next. In the first part, there is a literature review. The second part develops the methodological framework. This is followed by a presentation of the study's results, which are analyzed on the basis of elements found in the literature review. The last part of the work deals with the conclusions of the study, and future research routes are outlined.

\section{Literature Review}

Since the study analyzes the impact of organizational culture artifacts on the adoption of compassionate organizational practices as perceived by the employees of a public institution in Bogotá (Colombia), the following are de main aspects related to culture and its elements as well as the concept of compassion within organizations and its elements.

\subsection{Organizational Culture}

Organizational culture as a topic of study gained relevance at the end of the seventies (Pedraza-Álvarez, Obispo-Salazar, Vásquez-Gonzáles \& Gómez-Gómez, 2015). It is Andrew Pettigrew in 1979 who particularly contributes to the introduction of the term into the organizational scenario with his publication "On Studying Organizational Cultures" (Grueso, 2007).

The organizational culture is understood as the result of the meeting of several people who live in the same place and share attitudes and behaviors. In this sense "people who belong to a given culture share similar norms, history, values and artifacts which set them apart from others" (Belias \& Koustelios, 2014, p. 132).

One of the most accepted theses on organizational culture comes from Schein (1985), who defines it as a pattern of basic assumptions that has performed well enough to be considered valid, and thus should be taught to new members as the correct form of perceiving, thinking and feeling in relation to those problems. In a similar way Rousseau (1993) conceives culture as the set of cognitions shared by members of a given social unit, acquired through both social learning and the socialization processes which expose individuals to various cultural elements such as activities and interactions, communicated information and material artifacts which make up the social experience while at the same time provide its members with shared values and frameworks for understanding. Barney (1986) defines organizational culture as a complex set of values, beliefs, basic assumptions and symbols that define the form in which an enterprise conducts its business.

Complementing the above, Schein (1988) points out that culture comprises three levels: artifacts and creations, values and beliefs, and basic assumptions. Artifacts and creations are represented by the physical and social reality of the firm; they are the most visible and hence of easiest access and management. The level of values and beliefs is configured from the relational dynamics of the firm itself, and they are the mechanism to interpret cultural creations. Finally, there is a level of basic assumptions. These are the most difficult to reach since they belong to the structure of the organization and are composed by perceptions, thoughts, feelings and attitudes of its members

Bonavía and Quintanilla (1996) used the above understanding of organizational culture to build a scale to measure the artifacts and creations proposed by Schein (1988) in his model. With regard to cultural artifacts Bonavía (2006) states, moreover, that this is the level of easiest access through self-reporting questionnaires, given that it is composed of the most palpable and observable elements of the organizational culture, such as strategy, structure, norms, technology, human relations, selection systems, training, personnel evaluation and promotion, incentives, communication processes and conflict resolution. In this way the author proposed to understand these artifacts within the framework of two types of culture: traditional -X- and progressive -Y-, the former being understood as the one that prioritizes the short-term perspective, with orientation towards the economy, centralized, conservative in decision making, individualistic, competitive, normative, with poor 
personnel management practices, with transactional relationships, avoidance of conflict, low implementation of marketing strategies and a less than harmonious relationship with the natural environment. Thus, the progressive culture is understood as that which displays the exact opposite of the features just described.

\subsection{Compassion in Organizations}

The word compassion is derived from the Latin root passio, whose meaning is "to suffer" and the prefix com, "together", and it expresses the idea of common suffering (Lilius et al., 2011). According to Sexton and Thompson (2015), the definition of compassion has been confused and it has been related mainly to suffering. Kanov et al. (2004) argue that debates about its meaning date back to over two thousand years and that the concept has been approached from different perspectives, namely, theology, philosophy and sociology. Saunders (2015) for his part states that compassion has been very much used as a concept but it has not been the subject of sufficient debate.

In the organizational context the concept of compassion faces the same difficulties since there is little clarity about it. However, some authors have made notable progress in its definition. First, Dutton, Worline, Frost y Lilius (2006) define compassion as the realization, the feeling and the response to the suffering of the other. For Tsui (2013) compassion refers to an affective state and a wide class of emotional and behavioral responses which trigger the desire to help when one witnesses suffering. Furthermore, De Zulueta (2014) argues that compassion is a moral attitude, a feeling, a passion, a virtue, a moral weakness. Moon et al. (2016, p. 52), in turn, point out that "compassion can occur as a response to the suffering of another person, which implies seen it with other people's eyes, hearing it with other people's ears, feeling it likewise and take measures that reveal one's own compassion". Finally, for Dutton et al. (2014), compassion is "an interpersonal process which implies the realization, the feeling and the action to alleviate the suffering of another person" (p. 277).

With regard to this topic, Dutton et al. (2006) argue that compassion within organizations is a product of the organizational structure (social architecture), the action of the members of the organization (activation and mobilization of compassion) and the features that emerge from the suffering situation (of structural and symbolic nature). They add that at the organizational level this process starts with the presence of a pain signal called pain trigger, which causes the activation of compassion and which in turn is facilitated by the attributes of the social architecture composed of values, routines and social networks that are part of an organization.

More recently, Dutton et al. (2014) put forth a model to explain compassion within organizations based on the interpersonal and dynamic process between the sufferer (victim) and the focal actor (confronting the suffering situation). This model involves three contexts, namely, personal, relational and organizational (see Figure 1).

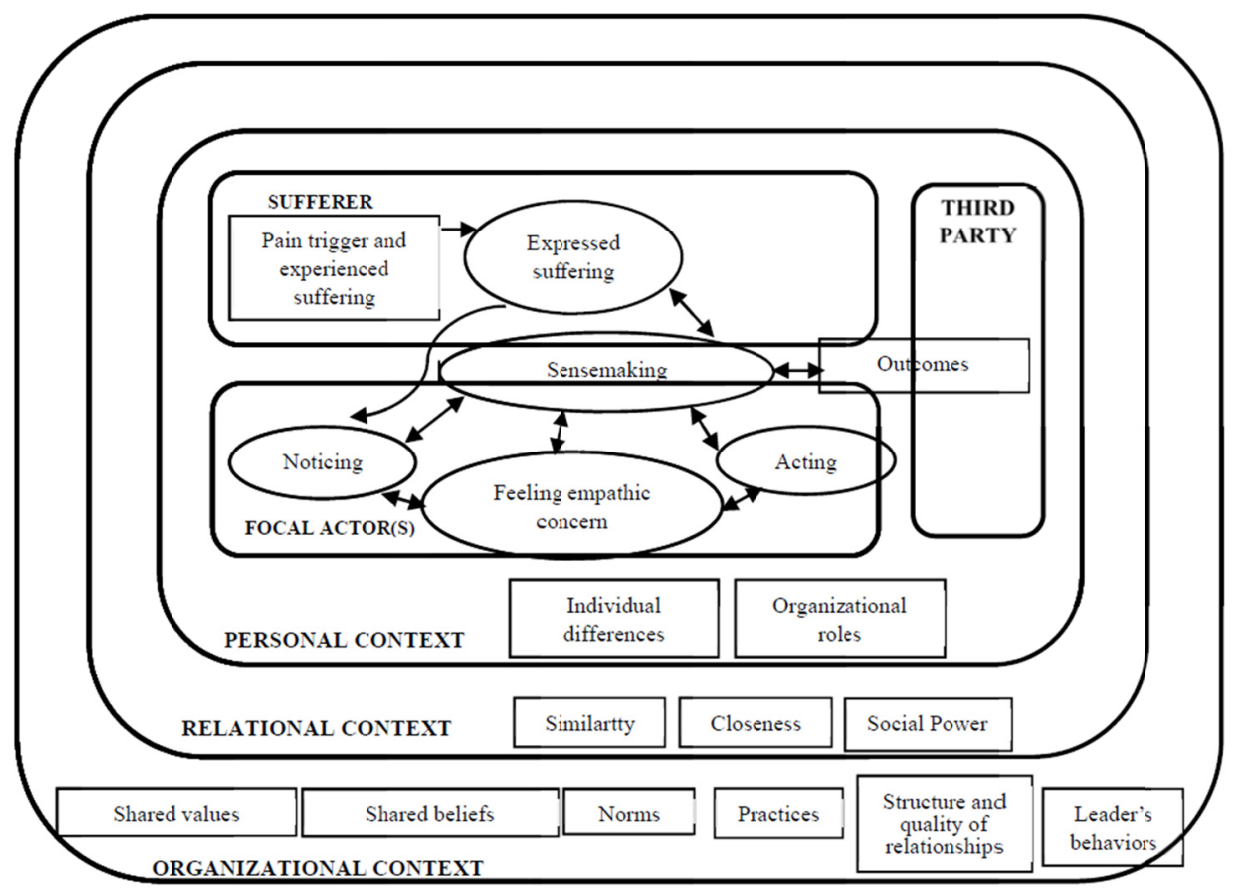

Figure 1. Interpersonal Process Compassion Model, Dutton et al. (2014, p. 282).

According to Dutton et al. (2014), compassion in the organizational context is determined by shared values and 
beliefs, behavioral norms, organizational practices, structure and quality of relationships and the leaders' conduct (see Figure 1). For these authors, shared values frame that which people believe to be important in the organization, and they contribute to the sensitization of people to compassionate responses. Shared beliefs demarcate what members of the organization accept as truth. Behavioral norms define the patterns that are to be expected from the organization.

In the same way, Dutton et al. (2014) define the organizational practices as those composed of personal practices that foster the implementation of support conducts between employees and towards them from the part organization, as well as the stimulation of these behaviors among the workers. Finally, Dutton et al. (2014) point out that compassion within organizations is also determined by the structure and quality of relationships between individuals of the organization and by the leaders' behavior before acts of compassionate nature since in their role they can potentially stimulate or hinder the practice of compassion.

\subsection{Culture and Compassion in Organizations}

Although in the realm of organizations compassion has received attention only in recent years, there is already evidence that supports the need to continue investigating the subject. For instance, Hur, Moon and Rhee (2016) discovered that compassion had an effect in the creativity of a group of workers of the sales section in stores of South Korea. These authors conclude that acts of compassion that form part of organizational routines contribute to the strengthening of a creative organizational culture.

There is some evidence of the direct relationship between culture and compassion in organizations (Delbecq, 2010; Martin, Dench \& Paku, 2016; Smith, Gentleman, Loads, \& Pullin, 2014). Martin et al. (2016), analyzed the factors of organizational culture and their association with compassion in a New Zealand school. The research took place in the period between 1962 and 2012, and employed in-depth semi-structured interviews of current and past general directors and executive directors of the school. The organizational culture was studied on the basis of Schein's Three Level Model, and the results confirm that compassion was a part of the organization's values. Smith et al (2014) explored the perceptions of eight nursing professors in the United Kingdom, under the participative action research design and using four reflection workshops. The study identified organizational culture as one of the four key aspects related to the practice of organizational compassion. Finally, among the studies which analyze the relationship between culture and compassion is the research carried out by Delbecq (2010), who develops an exploratory test by which he intends to determine how a higher education institution in the United States responds to crisis and suffering. His analysis led to the conclusion that universities are still far from expressing organizational compassion, and that culture may act as a restrictive element for this type of practices given that organizational culture in these contexts is more oriented towards issues of intellectual scope and leaves no room for the treatment of topics of a personal nature.

According to Shea (2015), compassion in not reduced to the interpersonal relationship but it encompasses the relational universe of the organization as a whole, and therefore, this author defends the idea of promoting an organizational culture based on compassion that privileges the workers' well-being. While it is true that compassion within organizations has been scantily studied (Kanov et al., 2004) and it is in its infancy (Dutton et al, 2014), for institutions such as hospitals and healthcare organizations it is an issue of special relevance (Lilius et al., 2011; Tierney, 2018). In the health sector it is appropriate to think about the concept of compassion and remember some of its attributes such as delicacy, recognition and support (Jiménez, Triana, \& Washburn, 2002). Based on all of the above, the stated aim of this investigation is to analyze the existing relationship between artifacts of the organizational culture and the compassion practices in a healthcare entity of the city of Bogotá.

\section{Method}

\subsection{Research Scope}

The investigation was carried out as a non-experimental study, trans-sectional of descriptive and correlational nature.

\subsection{Participants}

The research participants were healthcare professionals specialized in various fields from a public healthcare institution in Bogotá (Colombia). The choice of participants was made in a free and voluntary manner, and the decision to work with specialized healthcare professionals stems from the fact that in previous research, such as that of McClelland, Gabriel \& DePuccio, (2018) and McClelland \& Vogus (2014), the importance of compassionate practices among the healthcare personnel became apparent, since this creates a context which makes possible to facilitate, discover, feel and respond to suffering in a way that positively impacts the organization, its employees and patients. 


\subsection{Measurements}

There is no consensus on the optimal ways to study organizational culture. For some authors, the best way to approach it is through qualitative studies of ethnographic design. Others, however, suggest using numerical scales focused on the analysis of behavioral patterns or on values and beliefs (Grueso, 2009). To overcome difficulties brought about by the measurement of this construct Bonavía and Quintanilla (1996), Bonavía (2006) and Bonavía, Molina and Boada (2009) developed and adjusted an Organizational Culture Scale based on Artifacts (OCSA). By construction, the scale makes possible to distinguish between two different types of culture: Traditional Culture -X- and Progressive Culture -Y- (Bonavía \& Quintanilla, 1996), although the last revision of the scale (Bonavía et al., 2009) defends its one-dimensionality, oriented to evaluate only the Traditional Culture.

Some authors have defended the utility of studying organizational culture through artifacts that are the most visible aspects of the same (Bonavía, 2006; Bonavía et al., 2009; Bonavía \& Quintanilla, 1996), even though it is more recent and limited in comparison with other measurement methods. It is for this reason that in the present research the chosen option is to study culture at this level. Thus, the Organizational Culture Scale based on Artifacts (OCSA) adjusted by Bonavía et al. (2009) was applied. It contains 8 items and 6 response anchors (Totally agree $=6$, Totally disagree $=1$ ). A version of this scale was employed by Bonavía (2006) and the reported Cronbach's Alpha was 0,86 .

By contrast, the questionnaire on Compassionate Organizational Practices (COP), designed by Grueso and Rodríguez (2016), is based on the definition advanced by Dutton et al (2014) on compassionate organizational practices in accordance with the model of compassion in the workplace. According to Dutton et al, (2014), compassionate practices are composed of personal practices, actions that favor supportive behavior between employees, the development of supportive actions toward employees by the organization and the stimulation of supportive behavior among the members of the organization. The COP contains 16 items distributed among three factors: 1) support environment for third parties, 2) employee support and 3) human resources compassionate practices. In this context, the support environment for third parties is understood as the existence of an organizational environment that fosters the development of compassion practices aimed both at coworkers and at people from outside the organization. Actions such as the support of social causes or the emotional support to coworkers make up this factor. On the other hand, employee support can be construed as the creation of spaces that allow an employee the resolution of intra-personal and inter-personal conflicts, as well as the management of difficult emotional situations. Last, the human resources compassionate practices comprise the incorporation of values such as empathy and compassion in the processes of selection, induction, socialization, and training and performance evaluation. The 16 items are measured through 5 response anchors in a Likert- like scale (Totally agree $=5$, Totally disagree $=1$ ).

Table 1. KMO test, Bartlett's test of sphericity and Variance Total Explained

\begin{tabular}{|c|c|c|c|c|c|}
\hline $\begin{array}{l}\text { Measurement } \\
\text { Scale }\end{array}$ & Dimension & \# Items & $\begin{array}{c}\text { KMO } \\
\text { Test }\end{array}$ & $\begin{array}{c}\text { Barlett Sfericity } \\
\text { Test }\end{array}$ & $\begin{array}{c}\text { Explained total } \\
\text { variance }\end{array}$ \\
\hline \multirow{2}{*}{ OCSA } & Traditional culture & 5 & 0,740 & 0,00 & $56,587 \%$ \\
\hline & Progressive culture & 3 & & & \\
\hline \multirow{3}{*}{$\mathrm{COP}$} & Support environment for third- parties & 4 & & & \\
\hline & Employee support & 5 & 0,905 & 0,00 & $71,791 \%$ \\
\hline & Human resources compassionate practices & 7 & & & \\
\hline
\end{tabular}

In order to analyze the psychometric properties of the measurement scales employed in this research an exploratory factor analysis was carried out (EFA). This technique is used to reduce a large number of operational indicators to a manageable number of conceptual variables (Blalock, 1966). With regard to the Organizational Culture Scale based on Artifacts (OCSA), the Kaiser-Meyer-Olkin (KMO) test for sampling adequacy returned a value of 0,740 , Bartlett's test of sphericity test had a critical value of 0,00 and the Total Explained Variance was $56.58 \%$ with two factors (see Table 1), in contrast with the assumption of unidimensionality of the scale proposed by Bonavía et al (2009) but in accord with the antecedents of the same (Bonavía \& Quintanilla, 1996; Bonavía, 2006). Thus, the scale was composed of 8 items ( 5 which saturate the Traditional Culture component and 3 the Progressive Culture). As for the questionnaire on Compassionate Organizational Practices (COP), the Kaiser-Meyer-Olkin (KMO) test of sample adequacy returned 0,905 and Bartlett's test of sphericity a significant critical value of 0,00 , leading to the conclusion that the data is suited to factor analysis. In the analysis, the 16 items were grouped in three components that explain $71,791 \%$ of the Total Variance as illustrated in Table 1. 
Once the factors and their validity were identified and with the goal of identifying the consistence among the items composing each item, Cronbach's Alpha was computed. As seen in Table 2, all measurement scales gave Alphas between 0,65 and 0,92. According to Morales (2007) these values are satisfactory, since theoretical research has shown that a reliability value between 0,60 and 0,85 is considered appropriate.

Table 2. Reliability of the Measurement Scales

\begin{tabular}{ccccc}
\hline Measurement Scale & Dimentions & \# items & Mean & Cronbach's Alpha \\
\hline \multirow{2}{*}{ OCSA } & Traditional culture & 5 & 3,01 & 0,75 \\
& Progressive Culture & 3 & 4,01 & 0,65 \\
\multirow{2}{*}{ COP } & Support environment for third- parties & 4 & 2,97 & 0,80 \\
& Employee support & 5 & 2,85 & 0,92 \\
& Human resources compassionate practices & 7 & 3,21 & 0,92 \\
\hline
\end{tabular}

\subsection{Procedure}

In order to carry out the research, the Universidad del Rosario formally requested authorization from the institution under study. After obtaining a positive response from the latter, the information was collected through a questionnaire containing a demographic section, the artifact scale of culture and the scale of organizational compassion practices. The corresponding informed consent was administered likewise.

\section{Results}

\subsection{Sociodemographic Variables}

The results show that participants were $73,2 \%$ male and $26,8 \%$ female. As for age, it can be seen that first place corresponds to the age range $30-39$ years, with $36,6 \%$. Second place corresponds to the range $40-49$ years, with $31,3 \%$. Third place is occupied by the range $50-59$ years, with $20,5 \%$. Those with less than 30 years of age, $8,0 \%$, are in fourth place, and the last place, $3,6 \%$, corresponds to participants older than 60 . The most prevalent civil status is "married", with $61,6 \%$, and the least one, with $3,6 \%$, is "divorced". As for seniority and years in the office, personnel with over 10 years predominate with $28,6 \%$, while those with a range 7,1-10 years, with $12,5 \%$, are at the other end. Most of the employees, $78,6 \%$, have a professional level, and in the educational front the professional specialization, $79,5 \%$, stands out.

\subsection{Effects of Cultural Artifacts on Compassion Practices}

The goal of the investigation was to analyze the degree to which the artifacts of organizational culture have an effect on the adoption of compassionate organizational practices as measured by three components: support environment for third-parties, employee support and human resources compassionate practices. The results of the present research truly confirm that artifacts of the organizational culture predict the adoption of compassion practices within organizations as follows: support environment for third-parties $(r=0,346, p<0,01)$, employee support $(r=0,444 p<0,01)$, and human resources compassionate practices $(r=0,535, p<0,01)$, as illustrated in Table 3 .

Table 3. Effects of artifacts of organizational culture on the adoption of compassionate organizational practices

\begin{tabular}{ccccccccc}
\hline Model & & \multirow{2}{*}{$\mathrm{R}$} & \multirow{2}{*}{$\begin{array}{c}\text { Adjusted R } \\
\text { Square }\end{array}$} & $\begin{array}{c}\text { Std. Error of } \\
\text { the Estimate }\end{array}$ & \multicolumn{4}{c}{ Change Statistics } \\
\cline { 8 - 10 } & & Square & Square & $\begin{array}{c}\mathrm{F} \\
\text { Change }\end{array}$ & $\begin{array}{c}\text { Sig. F } \\
\text { Change }\end{array}$ & Change \\
\hline $\begin{array}{c}\text { Support environment for } \\
\text { third-parties }\end{array}$ & 0,346 &, 120 &, 104 &, 89138 &, 120 & 7,416 &, 001 \\
$\begin{array}{c}\text { Employees support } \\
\text { Compassionate Human } \\
\text { Resources Practices }\end{array}$ & 0,444 &, 197 &, 182 &, 93032 &, 197 & 13,376 &, 000 \\
\hline
\end{tabular}

Notes: Predictor: (Constant), traditional, progressive, $\mathrm{p}<0,01$

Now, when analyzing the degree of association and its significance between artifacts and compassion practices by culture (traditional and progressive), it is found that it is artifacts of progressive culture those that have a statistically significant effect on the adoption of compassion practices within organizations thus: help environment $(\mathrm{r}=0,347, \mathrm{p}<0,01)$, employee support $(\mathrm{r}=0,431 \mathrm{p}<0,01)$, and human resources compassion practices $(\mathrm{r}=0,410, \mathrm{p}<0,01)$, as illustrated in Table 4 . 
Table 4. Regression coefficients

\begin{tabular}{|c|c|c|c|c|c|c|}
\hline & & \multicolumn{2}{|c|}{ Unstandardized Coefficients } & \multicolumn{3}{|c|}{ Standardized Coefficients } \\
\hline & & B & Standar Error & Beta & $\mathrm{T}$ & Sig \\
\hline \multirow{3}{*}{$\begin{array}{l}\text { Support } \\
\text { environment for } \\
\text { third-parties }\end{array}$} & (Constant) & 1,722 & ,559 & & 3,079 & ,003 \\
\hline & Progressive & ,313 & ,092 & ,347 & 3,384 &, 001 \\
\hline & Traditional & 001 & 088 & ,001 & ,009 & ,993 \\
\hline \multirow{3}{*}{$\begin{array}{l}\text { Employees } \\
\text { support }\end{array}$} & (Constant) & 1,226 & ,584 & & 2,100 &, 038 \\
\hline & Progressive &, 425 & ,096 & ,431 & 4,404 &, 000 \\
\hline & Traditional &,- 025 & ,092 &,- 026 &,- 270 & ,788 \\
\hline \multirow{3}{*}{$\begin{array}{c}\text { Compassionate } \\
\text { Human Resources } \\
\text { Practices }\end{array}$} & (Constant) & 2,260 & ,499 & & 4,524 &, 000 \\
\hline & Progressive & ,367 & 083 & ,410 & 4,448 &, 000 \\
\hline & Traditional &,- 170 & 079 &,- 199 & $-2,161$ & 033 \\
\hline
\end{tabular}

Note: Independent variables: Traditional culture artifacts and progressive culture artifacts, $p<0,01, p<0,05$

\section{Results Analysis}

Given that research on the subject of compassion within organizations is limited (Chu, 2014; Dutton et al, 2014), the present study was done with the stated goal of analyzing the effect of artifacts of the organizational culture on the adoption of compassion practices in a healthcare entity in the city of Bogotá. With this aim a correlational and transectional study was conducted. The results obtained in the investigation provided confirmation that in the institution under study, the organizational culture, through its artifacts, has an effect on the adoption of compassion practices, which is in line with what was proposed by Dutton et al (2014) and the previous evidence obtained by Martin et al. (2016), and Smith et al. (2014).

In their theoretical model, Dutton et al (2014) state that the organizational culture, expressed through values, beliefs and shared norms, fosters the expression of compassion in organizational environments. Given that the organizational culture establishes the way of doing things (Barney, 1986), it is reasonable to see a link between culture and the three manifestations of compassion studied in the present investigation: help for third parties, employee support and human resources compassion practices. In previous discussions Dutton et al (2006) also pointed out that compassion within organizations is the product of the existence of a social architecture, constituted by the values that are part of the organization. The results obtained in the present investigation confirm this approach because, in effect, the organizational culture is a predictor of the adoption of compassion practices within the organization.

Compassion in organizations also requires the existence of a social architecture constituted by routines (Dutton et al, 2006). Therefore, it is not enough for the organization to have a system of values that express the importance of compassion, but it is necessary to have it operationalized through routines or organizational practices. From the relationship between organizational culture and compassion practices Martin et al. (2016), and Smith et al (2014) had already provided empirical evidence. For these authors the existence of compassion in organizations is possible insofar as this is part of the culture of the same. When analyzing the type of culture that predicts the adoption of compassionate organizational practices, the present investigation showed that the progressive organizational culture has a statistically significant effect on the creation of a support environment for third parties $(r=0.347, p<0,01)$, the creation of a support environment for employees $(r=0,431, p>0,01)$ and the adoption of human resources compassion practices $(r=0,410, p<0,01)$. In contrast to the above, traditional culture did not appear to be a statistically significant predictor in the adoption of compassionate organizational practices.

In the context of the present investigation, it was found that the artifacts of the progressive culture are associated with the existence of a support environment for third parties. Thus, the artifacts of a progressive culture would allow creating an organizational environment in which the notion of compassion is shared since, as Rousseau (1993) argues, culture is an optimal mechanism for the formation of shared cognitions. Compassion would be expressed not only towards people geographically closest to each other, i.e., the co-workers, but towards everyone who needs it, because as Bonavía and Quintanilla (1996) point out, progressive cultures are heavily focused on social issues.

The relationship between progressive culture and support environment for third parties also has another explanation. According to Belias and Koustelios (2014), people who belong to certain cultures share norms and 
artifacts that distinguish them from others. As a consequence, people who work in an organization with progressive culture would be more prone to adopt practices to help third parties.

Furthermore, when analyzing the predictive power of the artifacts of progressive culture on the creation of an atmosphere of support toward employees, the results indicate that this relationship exists. According to Bonavía and Quintanilla (1996), a progressive culture is more focused on the collective and cooperation. Thus, organizations with this approach will more easily adopt mechanisms to support employees - such as the resolution of intrapersonal and interpersonal conflicts - considered as a compassionate organizational practice by Dutton et al. (2014).

In the same way, the results obtained in the present investigation showed that the artifacts of the progressive culture significantly predict the adoption of compassionate human resources practices. In previous research it has been asserted that organizational culture determines the way human resources practices are carried out (Grueso, 2010) and the way a company conducts its business (Barney, 1986). Thus, an organization with a progressive organizational culture will more easily adopt human resources practices oriented towards personnel development, including the induction and training of staff. Likewise, organizations with a progressive organizational culture would develop evaluation systems which recognize not only the mastery of technical aspects but also values such as empathy and compassion.

Although the findings of this research are consistent with formulations made by authors such as Dutton et al (2014) and Martin et al. (2016), they contrast with the evidence provided by Delbecq (2010), who found that in university organizations, culture can act as a restrictive element of compassion. Despite the contradictory nature of this set of results, there could be some explanation to the extent that health organizations, unlike universities, have a focus on the person and his/her care consistent with the condition of vulnerability. In healthcare organizations, according to Jiménez et al (2002), it is pertinent to think about the concept of compassion and keep in mind some features of it, such as delicacy, recognition and support. It would be worthwhile, therefore, to inquire more about this aspect.

As for the measurement scales used to determine the relationships between the variables of the study, it is possible to emphasize that the Organizational Culture Scale based on Artifacts (OCSA) used in the present investigation behaved as a bi-dimensional scale, as opposed to the suggestion made by Bonavía et al. (2009), who assert that it is a one-dimensional scale. The above notwithstanding, the authors of the same recommend "to perform additional tests to assess concurrent and predictive validity, as well as other estimates that ensure the goodness of this scale" (p.10).

Another methodological aspect to be highlighted from this research is related to the questionnaire on Compassionate Organizational Practices (POC) designed by Grueso and Rodríguez (n.d.), which had no credentials in empirical exercises and in this research it showed an optimal behavior in terms of its psychometric properties.

\section{Conclusions}

The results obtained in the study allow us to conclude that the artifacts of the progressive culture have an effect on the adoption of compassionate practices in the organization under study. To demonstrate this, the Organizational Culture Scale based on Artifacts (OCSA) (Bonavía et al., 2009) and the questionnaire on Compassionate Organizational Practices (POC) (Grueso \& Rodríguez, n.d.) was used.

With respect to the effect of the artifacts of the organizational culture on the adoption of compassionate practices in the healthcare organization analyzed, it was found that artifacts of culture do indeed behave as boosters of compassion. After considering the results in more detail, the fact that progressive culture has a statistically significant effect on environment support practices, employee support and compassionate human resource practices, invites organizations in the healthcare sector to focus on the benefits of promoting a culture with these characteristics, taking into account that the adoption of compassion practices generates positive organizational results (Lulius et al., 2011) and that, on the contrary, an organization in which suffering is not contained incurs costs that comprise not only the financial dimension (Dutton et al, 2014; Moon et al., 2016).

The research suggests some challenges with respect to continuity in the study of the relationship between organizational culture and compassion. For example, it would be interesting to use measurement scales in other organizational contexts, with the intention of confirming the goodness and consistency of these instruments. On the other hand, it would be relevant to delve more deeply into the behavior of the relationship between culture and compassion beginning with the exploration of the other levels of culture considered by Schein (1988) in his model. 
Likewise, it would be advisable to venture into research with a mixed approach, in order to contrast the results obtained with the analysis of official documents of the organization and the discourse of the members of the same. Moreover, it would be relevant to compare organizations from different sectors in order to determine whether organizational culture operates as a driver of the adoption of compassion practices.

Given that the investigation was performed in a single organization, the generalization of the results brings forward some limitations. It is recommended, therefore, to complete more research with statistically representative samples. Finally, in spite of the limitations just mentioned, the investigation makes a contribution to the knowledge on the subject, which currently is still scarce.

\section{References}

Barney, J. B. (1986). Organizational culture: Can it be a sourced of sustained competitive advantage?, Academy of Management Review, 11(3), 656-665. https://doi.org/10.2307/258317

Beardsmore, E., \& McSherry, R. (2017). Healthcare workers' perceptions of organisational culture and the impact on the delivery of compassionate quality care. Journal of Research in Nursing, 22(1-2), 42-56. https://doi.org/10.1177/1744987116685959

Belias, D., \& Koustelios, A. (2014). Organizational culture and job satisfaction: A review. International Review of Management and Marketing, 4(2), 132-149.

Blalock, H. M. (1966). Estadística Social. México: Fondo de Cultura Económica

Bonavia, T. (2006). Preliminary organizational culture scale focused on artifacts. Psychological Reports, 99 , 671-674. https://doi.org/10.2466/PR0.99.3.671-674

Bonavía, T., \& Quintanilla, I. (1996). La cultura en las organizaciones y sus efectos sobre la participación de los empleados. Revista de Psicología del Trabajo y de las Organizaciones, 12(1), 7-26.

Bonavia, T., Molina, J. G., \& Boada, J. (2009). Further examination of the organizational culture scale of artifacts. Psychological Reports, 105(3), 827-834. https://doi.org/10.2466/PR0.105.3.827-834

Chu, L. Ch. (2016). Mediating positive moods: The impact of experiencing compassion at work. Journal of Nursing Management, 24, 59-69. https://doi.org/10.1111/jonm.12272

Correa, M. L. (2016). La humanización de la atención en los servicios de salud: un asunto de cuidado. Revista Cuidarte, 7(1), 1227-1231. https://doi.org/10.15649/cuidarte.v7i1.300.

De Zulueta, P. (2014). Compassion and the learning of medicine. Journal of Holistic Healthcare, 11(2), 12-16.

Delbecq, A. L. (2010). Organizational compassion: A litmus test for a spiritually centered university culture. J. of Management, Spirituality \& Religion, 7(3), 241-249. https://doi.org/10.1080/14766086.2010.499998

Dutton, J. E., Workman, K. M., \& Hardin, A. E. (2014). Compassion at work. Annual Review of Organizational Psy. \& Organizational Behavior, 1, 277-304. https://doi.org/10.1146/annurev-orgpsych-031413-091221

Dutton, J. E., Worline, M. C., Frost, P. J., \& Lilius, J. (2006). Explaning compassion organizing. Administrative Science Quarterly, 51(19), 59-96. https://doi.org/10.2189/asqu.51.1.59

Enríquez, I. (2015). Los estudios sobre el desarrollo en los senderos de las ciencias sociales latinoaméricanas. Cuadernos del Cendes, 32(90), 1-34. Retrieved from http://www.scielo.org.ve/scielo.php?script=sci_arttext \&pid $=$ S1012-25082015000300002

Friedman, H. H., \& Gerstein, M. (2017). Leading with compassion: The key to changing the organizational culture and achieving success. Psychosociological Issues in Human Resource Management, 5(1), 160-175.

Grueso, M. P. (2007). Antecedentes y consecuentes de las prácticas de recursos humanos: Revisión y análisis desde la perspectiva de género (Unpublished Doctoral Thesis). Universidad de Salamanca, España.

Grueso, M. P. (2010). Implementación de buenas prácticas de promoción de personal y su relación con la cultura y el compromiso con la organización. Innovar, 20(36), 79-90.

Grueso, M. P., \& Rodriguez, L. (2016). Escala de Prácticas Compasivas en las Organizaciones (Unpublished).

Hur, W. M., Moon, T., \& Rhee, S. Y. (2016). Exploring the relationships between compassion at work, the evaluative perspective of positive work-related identity, service employee creativity, and job performance. Journal of Services Marketing, 30(1), 103-114. https://doi.org/10.1108/JSM-05-2014-0180

Jiménez, A., Triana, M., \& Washburn, J. (2002). Compasión y Salud. Isegoría, 27, 211-223. https://doi.org/10.3989/isegoria.2002.i27.563 
Kanov, J. M., Maitlis, S., Worline, M. C., Dutton, J. E., Frost, P. J., \& Lilius, J. M. (2004). Compassion in $\begin{array}{llll}\text { organizational life. American Behavioral Scientist, } & \text { 47(6), }\end{array}$ https://doi.org/10.1177/0002764203260211

Lilius, J. M., Kanov, J., Dutton, J. E., Worline, M. C., \& Maitlis, S. (2011). Compassion revealed: What we know about compassion at work (and where we need to know more). In K. Cameron., \& G. Spreitzer (Eds), The Handbook of Positive Organizational Scholarship. Oxford University Press.

Lilius, J. M., Worline, M. C., Maitlis, S., Kanov, J., Dutton, J. E., \& Frost, P. (2008). The contours and consequences of compassion at work. J. of Org. Behavior, 29, 93-218. https://doi.org/10.1002/job.508

Martin, A. J., Dench, S., \& Paku, L. (2016). An exploration of Outward Bound New Zealand's organisational culture. Journal of Adventure Education and Outdoor Learning, 16(3), 206-221. https://doi.org/10.1080/14729679.2015.1122540

McClelland, L. E., Gabriel, A. S., \& DePuccio, M. J. (2018). Compassion practices, nurse well-being, and ambulatory patient experience ratings. Medical Care, 56(1), 4-10. https://doi.org/10.1097/MLR.0000000000000834

McClelland, L. E., \& Vogus, T. J. (2014). Compassion practices and HCAHPS: Does rewarding and supporting workplace compassion influence patient perceptions? Health Services Research, 49(5), 1670-1683. https://doi.org/10.1111/1475-6773.12186

Moon, T. W., Hur, W. M., Ko, S. H., Kim, J. W., \& Yoon, D. K. (2016). Positive work-related identity as a mediator of the relationship between compassion at work and employee outcomes. Human Factors and Ergonomics in Manufacturing \& Service Industries, 26(1), 84-94. https://doi.org/10.1002/hfm.20615

Morales, P. (2007). La fiabilidad de los test y escalas. Madrid: Universidad Pontificia Comillas, Facultad de Ciencias Humanas y Sociales.

O'brien, P. J. (2006). Creating compassion and connection in the work place. Journal of Systemic Therapies, 25(1), 16-36. https://doi.org/10.1521/jsyt.2006.25.1.16

Pedraza-Álvarez, L., Obispo-Salazar, K., Vásquez-González, L., \& Gómez-Gómez, L. (2015). Cultura organizacional desde la teoría de Edgar Schein: Estudio fenomenológico. Revista Clío América, 9(17), 17-25. https://doi.org/10.21676/23897848.1462

Rousseau, D. M. (1993). Teamwork: Inside and out. N.Y: Business Week Advance.

Saunders, J. (2015). Compassion. Journal of the Royal College of Physicians, 15(2), 121-124.

Schein, E. (1985). Organizational culture and the leadership. A dynamic view. San Francisco: Jossy-Bass.

Schein, E. (1988). La cultura empresarial y el liderazgo. una visión dinámica. España: Plaza \& Janes Editores.

Sexton, K., \& Thompson, Sh. (2015). Compassion leads to the creation of the backpack program in Kentucky-RESEARCH. Kentucky Journal of Excellence in College Teaching and Learning, 13(4), 1-12. Retrieved from http://encompass.eku.edu/kjectl/vol13/iss1/4.

Shea, S. (2015). Is it possible to develop a compassionate organization? Comment on "Why and how is compassion necessary to provide good quality healthcare? International Journal Health Policy Management, 4(11), 769-770. https://doi.org/10.1016/j.nedt.2014.03.003

Smith, S., Gentleman, M., Loads, D., \& Pullin, S. (2014). An exploration of a restorative space: A creative approach to reflection for nurse lecture's focused on experiences of compassion in the workplace. Nurse Education Today, 34(9), 1225-1231. https://doi.org/10.1016/j.nedt.2014.03.003

Tierney, S. (2018). What place does compassion hold in the conduct and production of health services research? Journal of Compassionate Health Care, 5(1), 1-6. https://doi.org/10.1186/s40639-018-0044-8

Tsui, A. (2013). 2012 Presidential Address-On compassion in scholarship: Why should we care? Academy of Management Review, 38(2), 167-180. https://doi.org/ia.5465/amr.2012.0408

\section{Copyrights}

Copyright for this article is retained by the author(s), with first publication rights granted to the journal.

This is an open-access article distributed under the terms and conditions of the Creative Commons Attribution license (http://creativecommons.org/licenses/by/4.0/). 